\title{
Enamel matrix protein derivatives: role in periodontal regeneration
}

This article was published in the following Dove Press journal:

Clinical, Cosmetic and Investigational Dentistry

30 November 2011

Number of times this article has been viewed

\author{
Vandana J Rathva \\ Department of Periodontics, \\ KM Shah Dental College and Hospital, \\ Sumandeep University, Gujarat, India
}

\begin{abstract}
The role of regenerative periodontal therapy is the reconstitution of lost periodontal structures, ie, new formation of root cementum, periodontal ligament, and alveolar bone. The outcome of basic research has pointed to the important role of enamel matrix protein derivative (EMD) in periodontal wound healing. Histologic results from animal and human studies have shown that treatment with EMD promotes periodontal regeneration. Moreover, clinical studies have indicated that treatment with EMD positively influences periodontal wound healing in humans. The goal of this paper is to review the existing literature on EMD.
\end{abstract}

Keywords: enamel matrix protein derivative, Emdogain ${ }^{\circledR}$, periodontal regeneration

\section{Introduction}

Therapeutic approaches to the treatment of periodontitis generally fall into two major categories, ie, those designed to halt the progression of periodontal attachment loss, and those designed to regenerate or reconstruct lost periodontal tissues. ${ }^{1}$ Regenerative periodontal therapy aims at the restitution of periodontal tissues that have been lost following inflammatory periodontal disease. ${ }^{2}$ Surgical procedures involving root conditioning, autograft, allograft, xenograft, and/or barrier membranes for guided tissue regeneration have been shown to contribute to a successful regenerative outcome. ${ }^{3}$ Despite the convincing histologic evidence that some regeneration may occur in humans following a regenerative surgical approach, ${ }^{4}$ complete and predictable regeneration is still a goal that is difficult to attain. In the last four decades, investigators have increased their efforts to seek procedures and materials promoting periodontal regeneration. Growth and differentiation factors have been shown to play a key role in wound healing, and it has been suggested that they could enhance the regenerative process. ${ }^{5}$ Moreover, periodontal regeneration has been demonstrated histologically using human platelet-derived growth factor BB mixed with bone allograft in both Class II furcation and interproximal intrabony defects. ${ }^{6}$ The use of growth factors has demonstrated significant repair and/or regeneration. ${ }^{7}$ The application of enamel matrix protein derivatives (EMD) was introduced as an alternative for obtaining periodontal regeneration. ${ }^{8,9}$

\section{Enamel matrix proteins in cementogenesis}

According to the classic theory of root formation and development of attachment apparatus, Hertwig's epithelial root sheath (HERS), which is the apical extension of the enamel organ, induces mesenchymal cells of the dental papilla to form the mantle predentin before it disintegrates and leaves the root surface. As a result of HERS 
apoptosis during the embryonic process, the physical barrier it forms between the mesenchymal cells of the dentinal follicle and the forming dentin disintegrates. The mesenchymal cells of the dentinal follicle and the forming dentin are induced to differentiate into cementoblasts, and are responsible for cementogenesis. The process of cementum deposition is a prerequisite for the formation of both the periodontal ligament and the alveolar bone. ${ }^{10}$ However, recombination between slices of root dentin and follicular cells has demonstrated that an exposed dentin surface is not a sufficient stimulus for cementoblast differentiation and cementogenesis. ${ }^{11}$ Instead, it appears that there is an obligatory intermediate short and specific modulating stage in which the HERS cells secrete enamel-related matrix proteins.

The enamel matrix is generally believed to regulate the initiation, propagation, termination, and maturation of hydroxyapatite crystallites in enamel. The enamel matrix also has a function outside the developing enamel. Enamel matrix proteins are temporarily deposited onto the dentinal root surface and provide an initial and essential step in the formation of a cellular cementum. ${ }^{12-14}$

Autoradiographic and scanning electron microscopy studies provide additional evidence that the cementogenesis process is initiated and kept modulated by these proteins following apoptosis of HERS cells and deposition of enamel matrix protein onto the dentin surface.

\section{Composition of enamel matrix proteins}

The major fraction of the enamel matrix proteins is composed of amelogenins, a family of hydrophobic proteins that account for more than $90 \%$ of the organic constituents of the enamel matrix. ${ }^{15}$ The amelogenins have remained remarkably well conserved through evolution, suggesting that they may have great functional importance. ${ }^{15}$

The second largest component of the enamel matrix protein is the enamelins. Enamelins have been found to contain serum proteins, and the more general term "non-amelogenin" is now commonly used to describe this high molecular weight fraction, which includes proline-rich enamelin, tuftelin, and tuft proteins.

Three matrix proteins, corresponding to amelogenin, enamelin, and sheathelin, and two enzymes, corresponding to MMP-20 and EMSP1, have been purified and the cDNA cloned from developing porcine teeth. Although early immunoassay studies could not identify the presence of growth factors in EMD, ${ }^{16}$ nominal levels of transforming growth factor $\beta 1$ have been detected immunologically. ${ }^{17}$ In addition, by using noggin, a bone morphogenic protein (BMP)-binding protein, investigators have identified BMP-2 and BMP-4 in an osteoinductive fraction of enamel extracts. ${ }^{18} \mathrm{~A}$ wide range of in vitro and in vivo studies have demonstrated that EMD and amelogenins stimulate growth of multiple mesenchymal cell types including fibroblasts, cementoblasts, osteoblasts, and stem cells. ${ }^{19,20}$ EMD and amelogenin enhance expression of tissue-specific maturation markers, such as alkaline phosphatase, collagen, and osteocalcin, within osseous tissues. ${ }^{21}$ The commercially available EMD (Emdogain ${ }^{\circledR}$, Biora AB, Malmo, Sweden) is available for the treatment of periodontal defects. Its acts as a tissue-healing modulator mimicking the events that occur during root development and helps to stimulate periodontal regeneration. ${ }^{8,9}$ The amelogenins, which are the hydrophobic constituents of the enamel matrix proteins, aggregate and become almost insoluble at physiologic $\mathrm{pH}$ and temperature. They can be dissolved in an acidic or alkaline $\mathrm{pH}$ environment and at low temperature. A suitable formulation should thus have a non-neutral $\mathrm{pH}$ and allow for gradual reprecipitation of the matrix when physiologic conditions are re-established. Using a buccal dehiscence model in monkeys, investigators evaluated several drug vehicles to determine which model most effectively allowed the EMD to precipitate on the treated root surface. ${ }^{8}$ Regeneration of cementum and alveolar bone was measured after 8 weeks. The results showed that propylene glycol alginate (PGA) was more effective than hydroxyethyl cellulose or dextran. PGA appears to enhance EMD precipitation, thus exposing the periodontal ligament cells to the re-established protein aggregate and allowing matrix-cell interactions to take place. The other vehicles that were tested, although stable at neutral $\mathrm{pH}$, appeared to prevent exposure of periodontal ligament cells to the proteins. ${ }^{8}$

\section{In vitro studies Properties of EMD}

Application of EMD results in limited epithelial downgrowth, in contrast with control sites where greater epithelial downgrowth takes place. This histologic observation was reinforced by in vitro studies. ${ }^{8}$ Addition of EMD to cell culture media resulted in enhanced proliferation of periodontal ligament cells, as well as increased protein and collagen production and mineralization. In contrast, EMD had no significant effect on epithelial cell proliferation in vitro. ${ }^{16}$ It may be concluded that the biochemical environment at the root surface following application of EMD may prevent epithelial downgrowth in a manner similar to the mechanical prevention achieved using a barrier membrane in guided tissue regeneration procedures..$^{22,23}$ 


\section{Mode of action of EMD}

EMD adsorbs to hydroxyapatite and collagen and also to denuded dental roots. It forms insoluble spherical complexes, and detectable amounts remain at the treated site on the root surface for up to 2 weeks, as was shown by radiolabeled protein in rats and pigs. This appears to be a sufficient period of time to permit recolonization by periodontal ligament cells or undifferentiated cells. ${ }^{16}$

In a series of laboratory studies, the effect of EMD on migration of mineralized nodules was examined. Immunoassays were performed to determine the possible presence of existing polypeptide factors. ${ }^{16,25}$ The results showed that, under in vitro conditions, EMD promotes the proliferation of periodontal ligament fibroblasts but not epithelial cells, and increases total protein synthesis of periodontal ligament fibroblasts as well as formation of mineralized nodules by periodontal ligament fibroblasts. In the above mentioned studies, no levels of specific molecules, such as insulin-like growth factor (IGF)-1 and IGF-2, human platelet-derived growth factor $\mathrm{BB}$, tumor necrosis factor, transforming growth factor $\beta$, interleukin- 6 , or platelet-derived growth factor $A B$ were compared with those in the control group. ${ }^{19}$ EMD has no appreciable effect on osteoclastic differentiation, although it stimulates cell growth and IGF-1 and transforming growth factor $\beta 1$ production in periodontal ligament cells. ${ }^{26}$ Palioto et al evaluated the effect of EMD, IGF-1, and a combination of these two factors on the proliferation, adhesion, migration, and expression of type I collagen in periodontal ligament fibroblasts, which were significantly stimulated by both EMD and EMD plus IGF-1 in a dose-dependent and timedependent manner. ${ }^{27}$ However, these factors did not affect the adhesion, migration, or expression of type I collagen by these cells. Other data indicate that EMD may contain additional mitogenic factors, such as transforming growth factor- $\beta$ and BMP-like growth factors that stimulate fibroblastic proliferation and contribute to the induction of biomineralization during periodontal regeneration..$^{28}$

Keila et al investigated the effects of EMD on rat bone marrow stromal cells and on gingival fibroblasts. ${ }^{29}$ EMD increased the osteogenic capacity of bone marrow and mineralized nodule formation. The presence of EMD in the initial stages (first 48 hours) of the culture was crucial for this effect. In contrast, EMD did not induce osteoblastic differentiation of gingival fibroblasts but increased both cell numbers and amount of matrix produced by up to two-fold. Upon further investigation, it was shown that the attachment, growth, and metabolic rate of periodontal ligament fibroblasts increased significantly when EMD was added to cell cultures and that EMD may convert the differentiation pathway of pluripotent $\mathrm{C} 2 \mathrm{C} 12$ mesenchymal cells into an osteoblast and/or chondroblast lineage. ${ }^{16,19}$ The cellular activities stimulated by EMD are not associated with a single molecular weight species. The fact that noggin abolishes $\mathrm{C} 2 \mathrm{C} 12$ alkaline phosphatase activity suggests that the effects on osteoprogenitor cell differentiation are the result of BMP-like protein(s), while the effects on proliferation and angiogenesis are associated with lower molecular weight species present in peaks II and III. Finally, unheated EMD displays gelatinolytic activities that are also detectable following size exclusion separation of EMD constituents. The masses of these activities were consistent with those reported for latent and active MMP-20. ${ }^{30}$ Periodontal ligament fibroblasts showed significantly increased alkaline phosphatase activity following application of EMD, which also enhanced the proliferation of human periodontal ligament fibroblasts..$^{31,32}$ In the presence of EMD, human periodontal ligament fibroblasts showed some morphologic changes that made them more similar to cementoblasts than to fibroblasts, suggesting a process of cell differentiation. A recent study examined the influence of EMD on the viability, proliferation, and attachment of periodontal fibroblasts to diseased root surfaces. ${ }^{33}$ The results indicated that cell viability was negatively affected by higher doses over time, while low doses displayed viability effects similar to those of the control. Periodontal ligament cell proliferation appeared to be ameliorated following exposure to EMD, and analysis by scanning electron microscopy suggested that cellular attachment to diseased dentin was enhanced following application of EMD. Further investigations demonstrated that EMD significantly increased mRNA synthesis of the matrix proteins, versican, biglycan, and decorin, and increased hyaluronan synthesis in gingival and desmosomal fibroblasts. It was also suggested that integrins are involved in the interaction between periodontal ligament cells, gingival fibroblasts, and EMD. ${ }^{34}$ However, it has to be emphasized that in most studies, EMD had a stronger effect on desmodontal than on gingival fibroblasts. Other experimental investigations have shown that the application of EMD can regulate the expression of genes associated with cementoblasts which, in turn, has a crucial effect on the mineralization process. ${ }^{35}$ Inoue et al evaluated if application of EMD to different dental materials which do not normally support cementogenesis, such as Gutta-percha, calcium hydroxide, amalgam, and super EBA cement, would alter the in vitro phenotype of periodontal ligament cells. Their findings indicated that EMD can alter the phenotype of periodontal ligament cells when cultured on 
these materials. However, some studies have failed to show an influence of EMD on the proliferation of mouse fibroblasts and marrow stromal cells. ${ }^{36}$ Very recent data have shown that neither EMD nor PGA has the ability to induce hard tissue and that the enamel matrix proteins contained within EMD might aggravate the dentin surface and inhibit the effect of demineralized dentin matrix. ${ }^{37}$ In a study investigating clot adhesion to protein-conditioned root surfaces, human dentin blocks were exposed to either a saturated citric acid solution or a commercial ethylene diamine tetra-acetic acid (EDTA) preparation using standardized protocols. ${ }^{38}$

In an in vitro study, the combination of EMD $4 \mathrm{mg}$ and active demineralized freeze-dried allogenic bone showed increased bone induction. It was concluded that EMD possesses osteopromotive but not osteoinductive characteristics when applied at certain concentrations. ${ }^{39}$ Schwarz et al have shown that EMD stimulates the early stages of osteoblast maturation by increasing cell proliferation. ${ }^{40}$ However, when applied to mature cell lines, the main effect was to influence cell differentiation. A stimulatory role of EMD on mineralized tissue formation by modulating regulatory molecules critical to bone metabolism at the RNA level has also been reported. ${ }^{41}$

Schwarz et al investigated the effects of EMD on attachment, proliferation, and viability of human Saos-2 osteoblastlike cells on titanium implants. The results indicated that EMD-enhanced proliferation and viability of human Saos-2 osteoblasts on sandblasted/acid-etched titanium implants is concentration-dependent. Treatment of osteoblasts with EMD significantly stimulated cell proliferation and fibroblast growth factor- 2 expression but decreased alkaline phosphatase expression. ${ }^{42}$ It was also suggested that EMD may elicit its mitogenic signal through an EMD-specific tyrosine kinase receptor towards extracellular signal regulated kinase $1 / 2 .{ }^{43}$ It seems that treatment with EMD may enhance the cellular activities of osteoblasts and osteoclasts, which in turn might support the regeneration of periodontal bony defects. ${ }^{44}$ Because soluble peptides released from EMD may contribute to the stimulating effects on cell proliferation, direct contact between EMD and osteoblasts might not be required to induce cell proliferation. ${ }^{45}$ Shimizu et al ${ }^{46}$ investigated the ability of EMD to regulate bone sialoprotein gene transcription in osteoblast-like cells. The findings identified EMD response elements in the rat bone sialoprotein gene promoter that may mediate the effects of EMD on bone sialoprotein gene transcription. EMD enhanced the proliferation of human mesenchymal stem cells and seemed to enhance mineralization. The reverse transcriptase polymerase chain reaction test revealed that EMD promoted early-stage osteoblast differentiation by enhancing collagen type I alpha 2 expression, but exerted an inhibitory effect on mineralization by lowering gene expression of bone sialoprotein and $\gamma$-carboxylglutamate.

Another study evaluated the effect of a bioactive glass and EMD combination on proliferation of MC3T3-E1, a mouse preosteoblastic cell line. ${ }^{47}$ Cells were cultured for up to 28 days in contact with three types of granules, ie, Bioglass 45S5 granules, 45S5 granules coated with EMD, and a less reactive glass used as the control. The results indicated that Bioglass 45S5 granules either alone or coated with EMD have the ability to support growth of osteoblastlike cells in vitro and promote osteoblast differentiation by stimulating the expression of major phenotypic markers. However, the bioactive granules coated with EMD showed significantly higher protein production than the bioactive granules alone.

Parker and Tonetti evaluated the selective effects of EMD on the activities of 268 cytokine, growth factor, and receptor genes in periodontal ligament tissue. ${ }^{48}$ The results indicated that EMD downregulates the expression of genes involved in the early inflammatory phases of wound healing while simultaneously up regulating genes encoding for molecules that promote growth and repair.

It is important to note that certain antibacterial effects and impairment of bacterial adherence were also found to be influenced by EMD. Plaque samples were allowed to accumulate for 4 days and were divided into five equal parts thereafter. ${ }^{49}$ Each part was mixed with $5 \mu \mathrm{L}$ of one of the following solutions: $\mathrm{NaCl}, \mathrm{EMD}$ in water, EMD in PGA vehicle, PGA vehicle, and chlorhexidine digluconate. Vital fluorescent microscopy was subsequently used to evaluate the vitality of the plaque flora. The results showed that EMD in the PGA vehicle had a very strong antibacterial effect. It was concluded that the antibacterial effect of EMD is mainly due to the effect of the PGA carrier. These findings were later confirmed in an observer-blind, randomized, five-cell crossover study, demonstrating for the first time a direct influence of EMD on the vitality of supragingival dental plaque in vivo. ${ }^{50}$ In a further investigation, it was shown that EMD inhibits the growth of the periodontal pathogenic bacteria Actinobacillus actinomycetemcomitans, Porphyromonas gingivalis, and Prevotella intermedia. Twenty-four hours following the application of EMD, no living colonies of these pathogenic bacteria could be observed. EMD demonstrated no negative effect on Gram positive bacteria. ${ }^{51}$ The inhibitory effect of EMD on periodontal pathogenic bacteria was also confirmed by others. ${ }^{52,53}$ 
Recent data also suggest that $P$. gingivalis diminishes the effect of EMD on periodontal ligament cells in vitro via the cooperative action of gingipains. ${ }^{54}$ Rincon et al evaluated the influence of EMD on cultured gingival, periodontal ligament, and dermal fibroblasts, using an in vitro model of wound healing. This study demonstrated that cells in vitro fill an empty space by a combination of proliferation and cell migration, indicating that EMD may exert an influence on cells involved in wound healing. ${ }^{55}$

In a study in rabbits, Mirastschijski et al ${ }^{56}$ primarily investigated the in vivo effects of EMD on skin wound healing. Secondly, they examined the in vitro effects of EMD on dermal fibroblasts and microvascular endothelial cells. Full-thickness, circular $2 \mathrm{~cm}$ skin wounds in 16-week-old white rabbits were treated three times a week with EMD $30 \mathrm{mg} / \mathrm{mL}$ in a PGA vehicle or with vehicle alone as a control. Treatment with EMD increased the amount of granulation tissue and accelerated the time taken to complete epithelialization by 3 days compared with the controls. Vascular endothelial growth factor levels in conditioned media were increased by more than five-fold with EMD treatment compared with the control treatment in cultured fibroblasts, as measured by enzyme-linked immunosorbent assay. EMD also increased the release of MMP-2 from fibroblasts and endothelial cells by more than three-fold. It was concluded that EMD significantly accelerated wound closure in rabbits, possibly by increasing the levels of growth factors and proteinases important for granulation tissue formation and granulation. ${ }^{56} \mathrm{It}$ was shown that EMD may express some angiogenetic effects, which could play an important role in early wound healing. ${ }^{57}$ Recent evidence points to EMD having antiinflammatory properties which attenuate the release of tumor necrosis factor- $\alpha$ and interleukin- 8 in whole blood from healthy donors challenged by lipopolysaccharide or peptidoglycan. ${ }^{58}$ Furthermore, it was shown that EMD inhibits attachment of MCF-7 (a typical breast cancer cell line) to bone matrix, suggesting that EMD might be useful as an antiadhesive agent for breast cancer cells to bone in vivo. ${ }^{59}$ EMD may affect gingival health by ways other than cell proliferation/survival, ie, by stimulation of tissue inhibitor of metalloproteinase (TIMP)-3 production, which could improve the MMP-TIMP balance in gingival tissue and curb extracellular matrix destruction. ${ }^{60}$ In conclusion, in vitro studies strongly indicate that EMD affects important wound healing mechanisms. However, to date, it appears that the underlying molecules and mechanisms are still not completely understood.

\section{Controlled histologic studies in animals}

In an experimental study in rats, the effects and distribution of EMD were studied in the periodontal tissue of maxillary rat molars transplanted to a subcutaneous position in the abdominal walls. ${ }^{61}$ Molars were transplanted with or without EMD, either immediately after extraction or after drying for 30 minutes. The rats were sacrificed after day 2 or weeks 1 , 2 , or 4 , and the teeth were examined by light microscopy and immunohistochemistry using antiamelogenin antibodies. The teeth that were transplanted immediately after extraction showed formation of alveolar bone separated from the dental roots by a periodontal space, regardless of the use of EMD. New alveolar bone was formed in five of eight teeth after weeks 2 and 4 in the teeth transplanted with EMD after drying for 30 minutes. None of the teeth transplanted without EMD showed alveolar bone formation. Additionally, one tooth transplanted with EMD showed root resorption after drying, while resorption was noted in all teeth transplanted without EMD. EMD was detected as early as day 2 on all the teeth transplanted with EMD and was still demonstrated after 4 weeks. ${ }^{62}$ However, this effect was limited to the first 4 weeks following surgery, indicating that the main effect of EMD is at the early stage of periodontal wound healing. In another study, defects were filled with either vehicle or EMD in rat periodontal window wounds, with no microbial biofilm or epithelial downgrowth. ${ }^{63}$ The results of this research indicated that EMD did not affect expression of differentiation markers or bone matrix protein synthesis in the repopulation response of wounded rat molar periodontium. It was suggested that the effect of EMD on wound healing in the periodontium may be independent of differentiation in the cell populations examined in the type of model used. ${ }^{63}$

In a controlled histologic study, recession defects were created and treated with EMD. ${ }^{64}$ Standardized defects were created by surgically removing the entire buccal bone plate and the root cementum. The test defects were treated with EMD, while a coronally repositioned flap was made in the control defects. Eight weeks after surgery, the animals were sacrificed and the appropriate jaw segments were evaluated histologically. The results showed that a new periodontium developed in all the tested defects. In the control defects, the healing was characterized by a long junctional epithelium with very limited cementum and new bone formation. If new cementum was formed in the control defects, it was mostly cellular and only partly attached at the root surface. Interestingly, in this study, no root resorption occurred in the test defects, but was a very frequent phenomenon in the control defects. 
It is important to note that no oral hygiene measures were carried out during the entire study period. In an experimental study in monkeys, acute fenestration-type defects were surgically created and subsequently treated with guided tissue regeneration (GTR), EMD, or coronally repositioned flaps (control). ${ }^{65}$ All three treatment approaches enhanced the formation of new connective tissue attachment and new bone, but there was no major difference between the treatment groups. The results also indicated that acute fenestration-type defects do not seem to be a suitable test model for determining the potential of any type of regenerative approach. ${ }^{65}$ In two subsequent studies in monkeys, recession-type and intrabony defects were surgically created and exposed to dental plaque infection. ${ }^{64,65}$ Following initial periodontal therapy consisting of oral hygiene measures with topical application of chlorhexidine, the defects were treated with GTR, EMD, EMD + GTR, or open flap debridement surgery (control). Histologic investigation showed healing of the control defects characterized by a long junctional epithelium and limited periodontal regeneration. Treatment with GTR, EMD, or EMD + GTR resulted in the formation of cementum with insertion of collagen fibers as well as formation of alveolar bone. ${ }^{66,67}$ Comparable results were also reported in rat, dog, and monkey defects, with either spontaneous intrabony and experimentally created intrabony, recession, or dehiscencetype defects. ${ }^{68-72}$

A histomorphometric study in dogs evaluated the effectiveness of EMD used for regeneration of periodontal tissues in class II furcation lesions with or without GTR. ${ }^{73}$ Experimental class II furcations were made in the premolars of four dogs. The furcation defects were filled with Guttapercha to induce an inflammatory response and to prevent spontaneous repair. Twenty-one days later, the defects were treated with GTR, EMD, or open flap debridement surgery. Histologic analysis at 8 weeks following therapy showed healing characterized by formation of a long junctional epithelium and limited bone formation in the control group. Treatment with EMD led to significant regeneration of furcation lesions, but association with membranes was detrimental. Another histologic study in monkeys evaluated healing of mandibular class III furcation defects following treatment with GTR, EMD, EMD + GTR, or open-flap debridement surgery. ${ }^{74}$ The results showed that treatment with GTR or EMD + GTR resulted in formation of new cementum with insertion of collagen fibers, and new bone was seen to be filling the defects where the membrane was not exposed. The sites treated only with EMD exhibited new attachment and new bone formation to a varying extent, while the control sites showed only limited new attachment and bone formation.

In conclusion, animal data indicate that EMD is present on treated root surfaces for a period of at least 4 weeks and predictably promotes formation of cementum and bone in fenestration, recession, intrabony, and mandibular class II furcation defects.

\section{Histologic studies in humans}

The first human histologic report assessing the effect of EMD on periodontal regeneration used a mandibular incisor scheduled for extraction due to orthodontic reasons. ${ }^{74}$ An experimental surgical procedure, intended to create a buccal dehiscence defect almost reaching the apex of the tooth, was performed in a setting identical to that of previously reported experimental defects in monkeys. Four months later, the experimental tooth, together with the surrounding soft and hard periodontal tissue, was removed surgically for histologic evaluation. Microscopic examination revealed formation of new acellular cementum, new periodontal ligament with inserting and functionally oriented collagen fibers, and associated alveolar bone. The new cementum covered $73 \%$ of the original defect. New bone gain was $65 \%$ of the presurgical bone height. ${ }^{75}$

In another study, Yukna and Melloning treated ten intrabony periodontal defects in eight patients with EMD. Histologic analysis 6 months later showed complete periodontal regeneration in three biopsies, and three further biopsies indicated healing characterized by new connective tissue attachment. ${ }^{76}$ These findings are confirmed in subsequent reports by others, not only in intrabony-type but also in recession-type defects. ${ }^{77-82}$ Subsequent immunohistologic studies have shown that, following surgery, EMD remains on the root surface for up to 4 weeks and the wound healing and/ or remodeling process can be followed for up to 6 months after treatment with EMD therapy. ${ }^{83,84}$

A very recent human histologic study attempted to characterize the tissues developing on the root surface at 2-6 weeks following treatment of intrabony defects with EMD. ${ }^{86,87}$ The results showed that the newly formed tissues on the root surfaces were thick, collagenous, devoid of extrinsic fibers, and had an irregular surface contour. The presence of electron-dense organic material in the collagenous matrix indicated at least partial mineralization. Embedded cells were numerous and the cells on the matrix surface were large in size. It was concluded that bone-like tissue resembling cellular intrinsic fiber cementum may develop on the root surfaces instead of acellular extrinsic fiber cementum following treatment with EMD. 


\section{Clinical safety of EMD}

Because the commercial formulation of EMD is a porcinederived xenograft, the potential for it to stimulate an immune reaction when used in humans is of extreme importance. The enamel matrix proteins are highly conserved among mammalian species, and exposure to these proteins takes place during tooth development in early childhood. Thus, tolerance should normally be induced and the proteins recognized by the immune system as "self" proteins. Therefore, it is reasonable to assume that they are less likely to act as antigens. In vitro studies show that EMD does not significantly modify cellular or humoral immune responses. Very high concentrations of EMD induced only a slight increase in proliferation of human lymphocytes, restricted to the CD25+ (interleukin-2 receptor) fraction of $\mathrm{CD} 4+\mathrm{T}$ lymphocytes. There was a concomitant decrease in B lymphocytes, while other cell fractions (CD8+ T cells, B cells, and natural killer cells) were not affected, and immunoglobulin and cytokine (interleukin-2 and interleukin-6) production was not modified. ${ }^{24}$

Moreover, it was shown that EMD attenuated the release of tumor necrosis factor- $\alpha$ and interleukin- 8 in whole blood from healthy donors challenged by lipopolysaccharide or peptidoglycan, but the release of interleukin-10 remained unchanged. EMD also produced a four-fold increase in the cAMP levels of peripheral blood mononuclear cell lysates, which in turn suggested that EMD has anti-inflammatory properties. ${ }^{85}$

\section{Controlled clinical studies in intrabony defects Nonsurgical periodontal therapy}

Two randomized, placebo-controlled clinical studies evaluated the effect of EMD as an adjunct to nonsurgical periodontal therapy in intrabony defects..$^{88,89}$

\section{Surgical periodontal therapy}

Data from controlled clinical studies have demonstrated that treatment of intrabony defects with EMD results in a significant reduction in probing depths and gain of clinical attachment. A randomized, placebo-controlled, multicenter study examined the effectiveness of EMD using the splitmouth procedure in 33 patients..$^{90}$ Results after 36 months showed a mean gain in clinical attachment of $2.2 \mathrm{~mm}$ in the test group and $1.7 \mathrm{~mm}$ in the control group. The radiologically determined bone gain amounted to $2.6 \mathrm{~mm}$ in the test group, with $66 \%$ filling of the bone defects. However, the control teeth did not show any bone gain. Another controlled clinical study showed that treatment with open flap surgery + EMD resulted in a three times greater defect fill than treatment with flap surgery alone (74\% defect fill after flap surgery + EMD versus $23 \%$ defect fill after flap surgery alone).$^{91}$ In a further prospective, controlled clinical study, 40 patients were treated by surgical therapy with two bioabsorbable barriers and the outcome compared with that of open flap surgery. ${ }^{92}$

A prospective, randomized, multicenter clinical study reported the treatment of intrabony defects using the papilla preservation technique with and without auxillary application of EMD ${ }^{93}$ From a total of 166 defects, 83 were treated with EMD and the remaining 83 acted as controls. After 1 year, the results showed a significantly higher clinical attachment gain in the test group than in the control group. ${ }^{93}$ However, a randomized, double-masked, placebo-controlled clinical trial failed to show significant differences in clinical and radiographic parameters following treatment of intrabony defects with open flap debridement and application of EMD or placebo. ${ }^{94}$ Generally, most of the data from controlled clinical studies indicate that the additional application of EMD in the context of surgical treatment of deep intrabony periodontal defects may lead to significantly higher gains in clinical attachment and defect fill compared with open flap debridement. ${ }^{95-100}$ Surgical treatment with EMD was also demonstrated to improve supracrestal soft tissue density significantly compared with open flap debridement alone. ${ }^{101,102}$ However, neither postoperative administration of amoxicillin and metronidazole nor selective cyclo-oxygenase 2 inhibitors appeared to enhance the clinical results. ${ }^{103,104}$ Furthermore, two studies have suggested that the clinical outcomes of intrabony defects treated with EMD do not depend on the use of EDTA root conditioning. ${ }^{105,106}$ Comparative studies reported similar results after treatment of intrabony defects with EMD or GTR, whereby the type of GTR barrier did not play a role. ${ }^{107,108}$

Clinical results with EMD are comparable with those after GTR therapy. A recent prospective multicenter, randomized, controlled clinical trial compared the clinical outcomes of EMD and GTR with a bioabsorbable membrane. ${ }^{108}$ The data indicate that the clinical outcomes after treatment of intrabony defects with EMD can be maintained over a longer time period. ${ }^{109,110,114}$ In a case cohort study, Cortellini and Tonetti indicated that a minimally invasive surgical technique combined with EMD in the regenerative treatment of isolated intrabony defects resulted in excellent clinical improvements while limiting patient morbidity. ${ }^{111}$ The use of a minimally invasive surgical technique with EMD promoted significant improvements in clinical parameters, with 
minimal pain/discomfort and maximum esthetic satisfaction in the treatment of intrabony defects. ${ }^{112}$ No additional clinical benefits were apparent when using Emdogain in comparison with sites treated with a placebo (the Emdogain carrier alone) in deep and wide intrabony defects. ${ }^{113}$

\section{Combination therapy for intrabony defects}

Experimental and clinical studies have indicated that the extent of regeneration is determined by the available space under the mucoperiosteal flap. ${ }^{115,116}$ Collapse of the mucoperiosteal flap may limit the area available for the regeneration process and may thus affect the result of therapy. In a prospective, controlled, clinical study, intrabony defects were evaluated following treatment with EMD, GTR, EMD + GTR, and open flap surgery. ${ }^{103}$ It was shown that all three regenerative treatment procedures resulted in a significantly greater improvement in clinical parameters compared with conventional flap surgery; however, combination therapy of EMD + GTR led to no additional improvement. A prospective, controlled split-mouth study in 11 patients with a total of 12 pairs of intrabony defects evaluated the clinical response of EMD with or without a tetracycline-coated expanded polytetrafluoroethylene barrier membrane at 6 and 12 months following therapy. ${ }^{117}$ Several studies have evaluated the effect of a combination of EMD and various types of bone graft/bone substitute in the treatment of intrabony defects. Human histologic studies indicate that a combination of EMD and a natural bone mineral or bioactive glass may indeed result in formation of root cementum and mineralization around the graft particles. ${ }^{118,119}$ Controlled clinical studies comparing treatment of intrabony defects with EMD and different types of bone graft/bone substitute seem to indicate that combination of EMD and demineralized freeze-dried allogenic bone or a natural bone mineral may enhance the clinical outcome. ${ }^{120,121,125,126}$ Sculean et al reported positive results from EMD in guided tissue regeneration in a 5-year and 10-year study. ${ }^{123,124}$

However, a recent study comparing the combination of EMD with a bioactive glass and EMD alone failed to show any significant differences between the two groups. ${ }^{125}$ Furthermore, clinical studies comparing treatment using a combination of EMD and a bone graft/bone substitute versus a bone graft/bone substitute alone did not demonstrate any advantage of the combination approach. ${ }^{130,131}$ Listl et al concluded that when monetary resources are high (ie, $>€ 150-200$ per additional $\mathrm{mm}$ of probing pocket depth reduction or clinical attachment gain, respectively), application of EMD (either alone or in combination with other devices) has a more advantageous cost-effectiveness ratio with respect to flap operation in cases where EMD is used with either bioactive glass or a bovine bone substitute, and has a more advantageous cost-effectiveness ratio than EMD alone; use of platelet-rich plasma or a resorbable membrane in addition to EMD and bovine bone grafts may only be justifiable when monetary resources for treatment are very generous. ${ }^{127}$ A combination of EMD + autogenous bone resulted in statistically significant greater soft and hard tissue improvements compared with treatment with EMD. ${ }^{128}$ Baltacioglu evaluated the clinical and radiographic results of intentional replantation of periodontally hopeless teeth with combined EMD and demineralized freeze-dried bone allograft therapy. ${ }^{129}$ Eleven patients with 12 periodontally hopeless teeth resulting from extensive alveolar bone loss and vertical defects extending to the apices were studied. At the 12-month clinical and radiographic followup, significant improvement was observed for all parameters except gingival recession $(P<0.05)$.

\section{Controlled clinical studies in recession defects}

In two controlled clinical studies, treatment of buccal Miller class I and II gingival recessions with a coronally positioned flap alone was examined using the split-mouth procedure. ${ }^{132,133}$ The clinical outcome did not show any differences between the therapies in terms of root coverage over a short time period of 1 year. However, additional application of EMD induced statistically significant greater formation of keratinized tissue, compared with that using a coronally positioned flap alone. ${ }^{133} \mathrm{~A}$ follow-up evaluation of this study showed that complete root coverage could be maintained in $53 \%$ of the EMD group compared with the control $(23 \%)$ over 2 years. ${ }^{134}$ Similar results were obtained in a randomized controlled clinical study of 58 contralateral sites in 17 patients with $\geq 2 \mathrm{~mm}$ Miller class I, II, and III buccal recessions treated with a coronally positioned flap and EMD (study group) or the flap alone (control group). ${ }^{135,136}$

In a controlled, clinical split-mouth study involving 17 patients, treatment of buccal Miller class II recessions with a coronally positioned flap and EMD (study group) or flap alone was compared with a connective tissue graft (control group). ${ }^{137}$ Comparable results were also reported in a multicenter, controlled clinical trial comparing the clinical efficacy of a coronally advanced flap procedure with the additional use of EMD (study group) and a subpedicle connective tissue graft (control group). ${ }^{138}$ The available data suggest that use of EMD may enhance the outcome of root coverage procedures, 
but additional application of a connective tissue graft seems to enhance further the formation of keratinized tissue. ${ }^{139}$ Kuru et al demonstrated in two cases the possibility of treating human buccal recessions with EMD plus a laterally sliding flap, with predictable root coverage and clinical attachment gain. ${ }^{140}$ Aroca et al showed that EMD did not enhance clinical outcome in the treatment of a class III recession-type defect when used with a modified tunnel/connective tissue graft technique compared with the modified tunnel/connective tissue graft technique alone. ${ }^{141}$ The additional use of EMD combined with a subepithelial connective tissue graft procedure does not produce a beneficial clinical outcome in terms of root coverage. ${ }^{142}$

\section{Controlled clinical studies in furcation defects}

A multicenter, randomized, controlled, split-mouth, clinical study compared treatment of mandibular class II furcation defects with 90 comparable defects on the contralateral molars. ${ }^{143,144}$ Defects were randomly assigned to treatment with EMD or GTR using a bioresorbable membrane. It was concluded that there was a significantly greater reduction in horizontal furcation depth and a comparatively lower incidence of postoperative pain/swelling following EMD than with GTR therapy. Casarin et al evaluated the response of proximal furcations treated with EMD in a prospective 24-month randomized clinical trial. ${ }^{145}$ At 24 months, the study group (open flap debridement + EDTA + EMD) showed a $1.9 \pm 1.6 \mathrm{~mm}$ probing depth reduction whereas the control group showed a $1.0 \pm 1.3 \mathrm{~mm}$ probing depth reduction. Relative horizontal clinical attachment levels were $0.7 \pm 1.3$ and $1.4 \pm 0.9 \mathrm{~mm}$, respectively. ${ }^{145}$

\section{Effect of EMD on early wound healing}

A quantitative study by Lafzi et al ${ }^{146}$ sought to illustrate the ultrastructural changes associated with a human gingival wound 10 days after application of EMD as an adjunct to a laterally positioned flap in a patient with gingival recession. Ten days after the operation, a gingival biopsy specimen was obtained from the dentogingival region and examined using a transmission electron microscope. A considerable difference was found in both the cellular and extracellular phases of the EMD and non-EMD sites. Fibroblasts at the EMD site were rounded with plump cytoplasm and euchromatic nuclei. Well-developed rough endoplasmic reticulum and numerous mitochondria could be detected. In contrast, the fibroblasts at the non-EMD site were of flattened spindle-like morphology. It seems that EMD may enhance certain features of gingival wound healing, which may be attributable to its anti-apoptotic, antibacterial, or anti-inflammatory properties. ${ }^{146}$

EMD as a pulpotomy agent in primary teeth has been also evaluated histologically. In a study of 10 carious primary canines among teeth deemed for serial extraction, Emdogain gel was used as a pulp dressing material on the amputated pulp stumps. Most of the teeth showed coalescing islands of dentin-like tissue trying to bridge the full width of the coronal pulp at the interface between the wounded and unharmed pulp tissue below the amputation site. ${ }^{147}$ New experiments now confirm that amelogenins present in Emdogain have the potential for use in endodontics, bone regeneration, implantology, traumatology, and wound care. ${ }^{148}$

\section{Conclusion}

Application of enamel matrix proteins in the form of Emdogain has set a modern standard for periodontal regeneration therapy. Surgical periodontal treatment of deep intrabony defects with EMD promotes periodontal regeneration. Surgical periodontal treatment of deep intrabony defects using EMD may lead to significantly greater improvements in clinical parameters compared with open flap debridement alone. The effect of treatment with EMD is comparable with that for GTR and can be maintained over a 10-year period. The combination of EMD and some types of bone graft/bone substitute may result in the soft and hard tissue parameters compared with treatment with EMD alone. Further studies are needed in order to clarify definitively the possible advantage of combination therapy using EMD and bone grafts/bone substitutes in relation to single therapies. Application of EMD seems to provide better long-term results than coronally repositioned flaps alone. Application of EMD may enhance periodontal regeneration in mandibular class II furcations, comparable with that obtained using GTR.

\section{Disclosure}

The author reports no conflicts of interest in this work.

\section{References}

1. Pihlstrom BL, Ammons WF. Treatment of gingivitis and periodontitis Research, science and therapy committee of the American Academy of Periodontology. J Periodontol. 1997;68:1246-1253.

2. Caton JG, Greenstein GG. Factors related to periodontal regeneration. J Periodontol. 2000;1993(1):9-15.

3. Garrett S. Periodontal regeneration around natural teeth. Ann Periodontol. 1996;1:621-666.

4. Bowers G, Chadroff B, Carnevale R, et al. Histologic evaluation of new attachment apparatus formation in humans. Parts I, II and III. J Periodontol. 1989;60:664-693. 
5. Giannobile WV. Potential role of growth factors and differentiation factors in periodontal regeneration. Position paper. American Academy of Periodontology. J Periodontol. 1996;67:545-553.

6. Nevins M, Camelo M, Nevins ML, Schenk RK, Lynch SE. Periodontal regeneration in humans using recombinant human platelet derived growth-BB (rhPDGF-BB) and allogenic bone. J Periodontol. 2003;74:1282-1292.

7. Venezia E, Goldstein M, Boyan BD, Schwartz Z. The use of enamel matrix derivative in the treatment of periodontal defects: a literature review and meta-analysis. Crit Rev Oral Biol Med. 2004; $15: 382-402$

8. Hammarstrom L. Enamel matrix, cementum development and regeneration. J Clin Periodontol. 1997;24:658-668.

9. Heijl L. Periodontal regeneration with enamel matrix derivative in one human experimental defect. A case report. $J$ Clin Periodontol. 1997;24:707-714.

10. Armitage GC. Cementum. In: Bhasker SN, editor. Orban's Oral Histology and Embryology. 11th ed. St Louis, MO: Mosby Co; 1991.

11. Thomas HF, Kollar EJ. Tissue interactions in normal murine root development. In: Davidovitc Z, editor. Proceedings of the International Conference on the Biological Mechanisms of Tooth Eruption and Root Resorption. Birmingham, AL: EBSCO Media; 1994.

12. Slavkin HC, Boyde A. Cementum: an epithelial secretory product? J Dent Res. 1975;53:157.

13. Slavkin HC. Towards a cellular and molecular understanding of periodontics. Cementogenesis revisited. J Periodontol. 1976;47: 249-255.

14. Slavkin HC, Diekwisch T. Molecular strategies of tooth enamel formation are highly conserved during vertebrate evolution. Ciba Found Symp. 1997;205:73-80.

15. Brookes SJ, Robinson C, Kirkham J, Bonnas WA. Biochemistry and molecular biology of amelogenin proteins of developing dental enamel. Arch Oral Biol. 1995;40:1-14.

16. Gestrelius S, Andersson C, Lidström D, Hammarström L, Somerman M. In vitro studies on periodontal ligament cells and enamel matrix derivative. J Clin Periodontol. 1997;24:685-692.

17. Kawase T, Okuda K, Momose M, Kato Y, Yoshie H, Burns DM. Enamel matrix derivative (Emdogain) rapidly stimulates phosphorylation of the MAP kinase family and nuclear accumulation of smad2 in both oral epithelial and fibroblastic human cells. J Periodontal Res. 2001;36:367-376.

18. Iwata T, Morotome Y, Tanabe T, Fukae M, Ishikawa I, Oida S. Nogging blocks osteoinductive activity of porcine enamel extracts. $J$ Dent Res. 2002;81:387-391

19. Lyngstadaas SP, Lundberg E, Ekdahl H, Andersson C, Gestrelius S. Autocrine growth factors in human periodontal ligament cells cultured on enamel matrix derivative. J Clin Periodontol. 2001;28: 181-188.

20. He J, Jiang J, Safavi KE, Spångberg LS, Zhu Q. Emdogain promotes osteoblast proliferation and differentiation and stimulates osteoprotegerin expression. Oral Surg Oral Med Oral Pathol Oral Radiol Endod. 2004;97:239-245.

21. Reseland JE, Reppe S, Larsen AM, et al. The effect of enamel matrix derivative (EMD) on gene expression in osteoblasts. Eur J Oral Sci. 2006;114:205-211.

22. Nyman S, Gottlow J, Karring T, Lindhe J. The regenerative potential of the periodontal ligament. J Clin Periodontol. 1982;9:257-265.

23. Gottlow J, Nyman S, Lindhe J, Karring T, Wennström J. New attachment formation in the human periodontium by guided tissue regeneration. Case reports. J Clin Periodontol. 1986;13:604-616.

24. Peteinaki E, Nikolopoulos S, Castanas E. Low stimulation of peripheral lymphocytes following in vitro application of Emdogain. J Clin Periodontol. 1998;25:715-720.

25. Hoang AM, Oates TW, Cochran DL. In vitro wound healing responses to enamel matrix derivative. J Periodontol. 2000;71:1270-1277.
26. Okubo K, Kobayashi M, Takiguchi T, et al. Participation of endogenous IGF-I and TGF-beta 1 with enamel matrix derivative stimulated cell growth in human periodontal ligament cells. $J$ Periodontol Res. 2003;38:1-9.

27. Palioto DB, Coletta RD, Graner E, Joly JC, de Lima AF. The influence of enamel matrix derivative associated with insulin like growth factor-I on periodontal ligament fibroblasts. $J$ Periodontol. 2004; $75: 498-504$

28. Suzuki S, Nagano T, Yamakoshi Y, et al. Enamel matrix derivative gel stimulates signal transduction of BMP and TGF- $\beta$. J Dent Res. 2005;84:510-514.

29. Keila S, Nemcovsky CE, Moses O, Artzi Z, Weinreb M. In vitro effects of enamel matrix proteins on rat bone marrow cells and gingival fibroblasts. J Dent Res. 2004;83:134-138.

30. Johnson DL, Carnes D, Steffensen B, Cochran DL. Cellular effects of enamel matrix derivative are associated with different molecular weight fractions following separation by size exclusion chromatography. J Periodontol. 2009;80:648-656.

31. Van der Pauw MT, Van den Bos T, Everts V, Beertsen W. Enamel matrix derived protein stimulates attachment of periodontal ligament fibroblast and enhances alkaline phosphatase activity and transforming growth factor $\beta 1$ release of periodontal ligament and gingival fibroblasts. J Periodontol. 2000;71:31-43.

32. Cattaneo V, Rota C, Silvestri M, et al. Effects of enamel matrix derivative on human periodontal fibroblasts: proliferation, morphology and root surface colonization. An in vitro study. $J$ Periodontal Res. 2003;38:568-574.

33. Davenport DR, Mailhot JM, Wataha JC, Billman MA, Sharawy MM, Shrout MK. Effects of enamel matrix protein application on the viability, proliferation, and attachment of human periodontal ligament fibroblasts to diseased root surfaces in vitro. $J$ Periodontol. 2003;30:125-131

34. Van der Pauw MT, Everts V, Beertsen W. Expression of intergrins by human periodontal ligament and gingival fibroblasts and their involvement in fibroblast adhesion to enamel matrix-derived proteins. J Periodontal Res. 2002;37:317-323.

35. Tokiyasu Y, Takata T, Saygin E, Somerman M. Enamel factors regulate expression of genes associated with cementoblasts. J Periodontol. 2000;71:1829-1839.

36. Gurpinar A, Onur MA, Cehreli ZC, Tasman F. Effect of enamel matrix derivative on mouse fibroblasts and marrow stromal osteoblasts. J Biomater Appl. 2003;18:25-33.

37. Koike Y, Murakami S, Matsuzaka K, Inoue T. The effect of Emdogain on ectopic bone formation in tubes of rat demineralized dentin matrix. J Periodontal Res. 2005;40:385-394.

38. Baker DL, Stanley Pavlow SA, Wikesjo UM. Fibrin clot adhesion to dentin conditioned with protein constructs: an in vitro proof-of-principle study. J Clin Periodontol. 2005;32:561-566.

39. Boyen BD, Weesner TC, Lohmann CH, et al. Porcine fetal enamel matrix derivative enhances bone formation induced by demineralized freeze dried bone allograft in vivo. $J$ Periodontol. 2000;71:1278-1286.

40. Schwarz Z, Carnes DL Jr, Pulliam R, et al. Porcine fetal enamel matrix derivative stimulates proliferation but not differentiation of pre-osteoblastic 2T9 cells inhibits proliferation and stimulates differentiation of osteoblast-like MG63 cells, and increases proliferation and differentiation of normal human osteoblast NHOst cells. J Periodontol. 2000;71:1287-1296.

41. Takayanagi K, Osawa G, Nakaya H, Cochran DL, Kamoi K, Oates TW. Effects of enamel matrix derivative on bone-related mRNA expression in human periodontal ligament cells in vitro. $J$ Periodontol. 2006;77:891-898.

42. Mizutani S, Tsuboi T, Tazoe M, Koshihara Y, Goto S, Togari A. Involvement of FGF-2 in the action of Emdogain on normal human osteoblastic activity. Oral Dis. 2003;9:210-217. 
43. Matsuda N, Horikawa M, Watanabe M, Kitagawa S, Kudo Y, Takata T. Possible involvement of extracellular signal-regulated kinases $1 / 2$ in mitogenic response of periodontal ligament cells to enamel matrix derivative. Eur J Oral Sci. 2002;110:439-444.

44. Hägewald S, Pischon N, Jawor P, Bernimoulin JP, Zimmermann B. Effects of enamel matrix derivative on proliferation and differential of primary osteoclast. Oral Surg Oral Med Oral Pathol Oral Radiol Endod. 2004;98:243-249.

45. He J, Jiang J, Safavi KE, Spångberg LS, Zhu Q. Direct contact between enamel matrix derivative (EMD) and osteoblasts is not required for EMD-induced cell proliferation. Oral Surg Oral Med Oral Pathol Oral Radiol Endod. 2004;98:370-375.

46. Shimizu E, Nakajima Y, Kato N, et al. Regulation of rat bone sialoprotein gene transcription by enamel matrix derivative. $J$ Periodontol. 2004; 75:260-267.

47. Hattar S, Asselin A, Greenspan, Oboeuf M, Berdal A, Sautier JM. Potential of biomimetic surfaces to promote in vitro osteoblast-like cell differentiation. Biomaterials. 2005;26:839-848.

48. Parker MH, Tonetti M. Gene expression profiles of periodontal ligament cells treated with enamel matrix proteins in vitro: analysis using cDNA arrays. J Periodontol. 2004;75:1539-1546.

49. Sculean A, Auschill TM, Donos N, Brecx M, Arweiler NB. Effect of an enamel matrix derivative $\left(\right.$ Emdogain $\left.{ }^{\mathbb{R}}\right)$ on ex vivo dental plaque vitality. J Clin Periodontol. 2001;28:1074-1078.

50. Arweiler NB, Auschill TM, Donos N, Sculean A. Antibacterial effect of an enamel matrix protein derivative in vivo dental biofilm vitality. Clin Oral Investig. 2002;6:205-209.

51. Spahr A, Lyngstadaas SP, Boeckh C, Andersson C, Podbielski A, Haller B. Effect of the enamel matrix derivative Emdogain on the growth of periodontal pathogens in vitro. J Clin Periodontol. 2001;29: $62-72$.

52. Newman SA, Coscia SA, Jotwani R, Iacono VJ, Cutler CW. Effects of enamel matrix derivative on Porphyromonas gingivalis. J Periodontol. 2003;74:1191-1195.

53. Walter C, Jawor P, Bernimoulin JP, Hägewald S. Moderate effect of enamel matrix derivative (Emdogain Gel) on Porphyromonas gingivalis growth in vitro. Arch Oral Biol. 2006;51:171-176.

54. Inaba H, Kawai S, Nakayama K, Okahashi N, Amano A. Effects of enamel matrix derivative on periodontal ligament cells in vitro is diminished by Porphyromonas gingivalis. $J$ Periodontol. 2004;75:858-865.

55. Rincon JC, Haase HR, Bartold PM. Effect of Emdogain on human periodontal fibroblasts in an in vitro wound healing model. J Periodontal Res. 2003;30:732-738.

56. Mirastschijski U, Konrad D, Lundberg E, Lyngstadaas SP, Jorgensen LN, Agren MS. Effects of a topical enamel matrix derivative on skin wound healing. Wound Repair Regen. 2004;12:100-108.

57. Yuan K, Chen CI, Lin MT. Enamel matrix derivative exhibits angiogenic effect in vitro and in a murine model. $J$ Clin Periodontol. 2003;30:732-738.

58. Myhre AE, Lyngstaadas SP, Dahle MK, et al. Anti-inflammatory properties of enamel matrix derivatives in human blood. J Periodontal Res. 2006;41:208-213

59. Zeldich E, Koren R, Dard M, Weinberg E, Weinreb M, Nemcovsky CE. Enamel matrix derivative induces the expression of tissue inhibitor of matrix metalloproteinase-3 in human gingival fibroblasts via extracellular signal-regulated kinase. J Periodontal Res. 2010;45: 200-206.

60. Takayama T, Suzuki N, Narukawa M, Goldberg HA, Otsuka K, Ito K. Enamel matrix derivative is a potent inhibitor of breast cancer cell attachment to bone. Life Sci. 2005;76:1211-1221.

61. Hamamoto Y, Kawasaki N, Jarnbring F, Hammarström L. Effects and distribution of the enamel matrix derivative Emdogain in the periodontal tissues of rat molars transplanted to the abdominal wall. Dent Traumatol. 2002;18:12-33.
62. Onodera H, Shibukawa Y, Sugito H, Ota M, Yamada S. Periodontal regeneration in intrabony defects after application of enamel matrix proteins with guided tissue regeneration: an experimental study in dogs. Biomed Res. 2005;26:69-77.

63. Chano L, Tenenbaum HC, Lekic PC, Sodek J, McCulloch CA. Emdogain regulation of cellular differentiation in wounded rat periodontium. J Periodontal Res. 2003;38:164-174.

64. Hammarström L, Heijl L, Gestrelius S. Periodontal regeneration in a buccal dehiscence model in monkeys after application of enamel matrix proteins. J Clin Periodontol. 1997;24: 669-677.

65. Sculean A, Donos N, Brecx M, et al. Healing of fenestration-type defects following treatment with guided tissue regeneration or enamel matrix proteins: an experimental study in monkeys. Clin Oral Investig. 2000;4:50-56

66. Sculean A, Donos N, Reich E, et al. Healing of recession-type defects following treatment with enamel matrix proteins or guided tissue regeneration: a pilot study in monkeys. $J$ Periodontol Implant Orale. 2000;19:19-31.

67. Sculean A, Donos N, Brecx M, Reich E, Karring T. Treatment of intrabony defects with enamel matrix proteins and guided tissue regeneration: an experimental study in monkeys. $J$ Clin Periodontol. 2000;27:466-472.

68. Sakallioğlu U, Açikgöz G, Ayas B, Kirtiloğlu T, Sakallioğlu E. Healing of periodontal defects treated with enamel matrix proteins and root surface conditioning - an experimental study in dogs. Biomaterials. 2004; $25: 1831-1840$

69. Nemcowsky CE, Zahavi S, Moses O, et al. Effect of enamel matrix protein derivative on healing of surgical supra-infrabony periodontol defects in the rat molar: a histomorphometric study. $J$ Periodontol. 2006;77:996-1002.

70. Sallum EA, Casati MZ, Caffesse RG, Funis LP, Nociti Júnior FH, Sallum AW. Coronally repositioned flap with or without enamel matrix protein derivative for the treatment of gingival recessions. Am J Dent 2003;16:287-291.

71. Sallum EA, Pimentel SP, Saldanha JB, et al. Enamel matrix derivative and guided tissue regeneration in the treatment of dehiscence type defects: a histomorphometric study in dogs. $J$ Periodontol. 2004;75:1357-1363.

72. Chochran DL, King GN, Schoolfield J, Velasquez-Plata D, Mellonig JT, Jones A. The effect of enamel matrix proteins on periodontal regeneration as determined by histological analyses. $J$ Periodontol. 2003;4:1043-1055.

73. Regazzini PF, Novaes AB Jr, de Oliveira PT, et al. Comparative study of enamel matrix derivative with or without GTR in the treatment of class I furcation lesions in dogs. Int $J$ Periodontics Restorative Dent. 2004;24:476-487.

74. Donos N, Sculean A, Glavind L, Reich E, Karring T. Wound healing of degree III furcation involvement following guided tissue regeneration and/or Emdogain: a histologic study. $J$ Clin Periodontol. 2003;30:1061-1068.

75. Heij1 L. Periodontol regeneration with enamel matrix in one human experimental defect: a case report. J Clin Periodontol. 1997;24:693-696.

76. Yukna RA, Melloning J. Histologic evaluation of periodontal healing in humans following regenerative therapy with enamel matrix derivative: a 10-case series. J Periodontol. 2000;71: $752-759$.

77. Melloning JT. Enamel matrix derivative for periodontal reconstructive surgery: technique and clinical and histologic case report. Int J Periodontics Restorative Dent. 1999;19:9-19.

78. Sculean A, Chiantella GC, Windisch P, Donos N. Clinical and histological evaluation of treatment of intrabony defects with an enamel matrix derivative $\left(\right.$ Emdogain $\left.^{\circledR}\right)$. Int $J$ Periodontics Restorative Dent. 2000;20:375-381. 
79. Majzoub Z, Bobbo M, Atiyeh F, Cordioli G. Two patterns of histologic healing in an intrabony defect following treatment with an enamel matrix derivative: a human case report. Int J Periodontics Restorative Dent. 2005;25:283-294.

80. Rasperini G, Silvestri M, Schenk RK, Nevins ML. Clinical and histological evaluation of human gingival recession treated with a subepithelial connective tissue graft and enamel matrix derivative (Emdogain): a case report. Int $J$ Periodontics Restorative Dent. 2000;20:269-275.

81. Carnio J, Camargo PM, Kenney EB, Schenk RK. Histological evaluation of 4 cases of root coverage following a connective tissue graft combined with an enamel matrix derivative preparation. J Periodontol. 2002;73:1534-1543.

82. McGuire MK, Cochran DL. Evaluation of human recession defects treated with coronally advanced flaps and either enamel matrix derivative or connective tissue. 2. Histological evaluation. J Periodontol. 2003;74:1126-1135.

83. Sculean A, Windisch P, Keglevich T, Fabi B, Lundgren E, Lyngstadaas PS. Presence of an enamel matrix protein derivative on human teeth following periodontal surgery. Clin Oral Investig. 2002;6: 183-187.

84. Sculean A, Junker R, Donos N, Windisch P, Brecx M, Dünker N. Immunohistochemical evaluation of matrix molecules associated with wound healing following treatment with an enamel matrix protein derivative in humans. Clin Oral Investig. 2003;7:167-174.

85. Froum S, Weinberg M, Novak J, et al. A multicenter study evaluating the sensitization potential of enamel matrix derivative after treatment of two intrabony defects. J Periodontol. 2004;75: 1001-1008.

86. Bosshardt DD, Sculean A, Windisch P, Pjetursson BE, Lang NP. Effects of enamel matrix proteins on tissue formation along the roots of human teeth. J Periodontal Res. 2005;40:158-167.

87. Bosshardt DD, Sculean A, Donos N, Lang NP. Patterns of mineralization after periodontal tissue engineering with enamel matrix proteins. Eur J Oral Sci. 2006;114 Suppl 1:225-231.

88. Gutierrez MA, Mellonig JT, Cochran DL. Evaluation of enamel matrix derivative as an adjunct to non-surgical periodontal therapy. $J$ Clin Periodontol. 2003;30:739-745.

89. Mombelli A, Brochut P, Plagnat D, Casagni F, Giannopoulou C. Enamel matrix proteins and systemic antibiotics as adjuncts to nonsurgical periodontal treatment: clinical effects. J Clin Periodontol. 2005;32:225-230.

90. Heijl L, Heden G, Svärdström G, Ostgren A. Enamel matrix derivative (Emdogain) in the treatment of intrabony periodontal defects. J Clin Periodontol. 1997;24:705-714.

91. Froum SJ, Weinberg MA, Rosenberg E, Tarnow D. A comparative study utilizing open flap debridement with and without enamel matrix derivative in the treatment of periodontal intrabony defects: a 12-month re-entry study. J Periodontol. 2001;72:25-34.

92. Pontoriero R, Wennstrom J, Lindhe J. The use of barrier membranes and enamel matrix proteins in the treatment of angular bone defects: a prospective controlled clinical study. J Clin Periodontol. 1999;26:833-840.

93. Tonetti MS, Lang NP, Cortellini $\mathrm{P}$, et al. Enamel matrix proteins in the regenerative therapy of deep intrabony defects: a multicenter randomized controlled clinical trial. J Clin Periodontol. 2002;29: 317-325.

94. Rösing CK, Aass AM, Mavropoulos A, Gjermo P. Clinical and radiographic effects of enamel matrix derivative in the treatment of intrabony periodontal defects: a 12 -months longitudinal placebocontrolled clinical trial in adult periodontitis patients. J Periodontol. 2005;76:129-133.

95. Okuda K, Momose M, Miyazaki A, et al. Enamel matrix derivative in the treatment of human intrabony osseous defects. $J$ Periodontol. 2000;71:1821-1828.
96. Silvestri M, Ricci G, Rasperini G, Sartori S, Cattaneo V. Comparison of treatments of intrabony defects with enamel matrix derivative, guided tissue regeneration with a nonresorbable membrane and Widman modified flap: a pilot study. J Clin Periodontol. 2000;27:603-610.

97. Sculean A, Windisch P, Chiantella GC, Donos N, Brecx M, Reich E. Treatment of intrabony defects with enamel matrix proteins and guided tissue regeneration: a prospective controlled clinical study. J Clin Periodontol. 2001;28:397-403.

98. Zucchelli G, Bernardi F, Montebugnoli L, De SM. Enamel matrix proteins and guided tissue regeneration with titanium-reinforced expanded polytetrafluroethylene membranes in the treatment of intrabony defects: a comparative controlled clinical trial. J Periodontol. 2002;73:3-12.

99. Silvestri M, Sartori S, Rasperini G, Ricci G, Rota C, Cattaneo V. Comparison of infrabony defects treated with enamel matrix derivative versus guided tissue regeneration with a nonresorbable membrane. J Clin Periodontol. 2003;30:386-393.

100. Wachtel H, Schenk G, Böhm S, Weng D, Zuhr O, Hürzeler MB. Microsurgical access flap and enamel matrix derivative for the treatment of periodontal intrabony defects: a controlled clinical study. J Clin Periodontol. 2003;30:496-504.

101. Yilmaz S, Kuru B, Altuna-Kiraç E. Enamel matrix proteins in the treatment of periodontal sites with horizontal type of bone loss. J Clin Periodontol. 2003;30:197-206.

102. Tonetti MS, Fourmousis I, Suvan J, et al; European Research Group on Periodontology (ERGOPERIO). Healing postoperative morbidity and patient perception of outcomes following regenerative therapy of deep intrabony defects. $J$ Clin Periodontol. 2004;31: 1092-1098.

103. Sculean A, Blaes A, Arweiler N, Reich E, Donos N, Brecx M. The effect of postsurgical antibiotics on the healing of intrabony defects following treatment with enamel matrix proteins. $J$ Periodontol. 2001;72:190-195.

104. Sculean A, Berakdar M, Donos N, Auschill TM, Arweiler NB. The effect of postsurgical administration of a selective cyclooxygenase-2 inhibitor on the healing of intrabony defects following treatment with enamel matrix proteins. Clin Oral Investig. 2003;7: $108-112$.

105. Parashis AO, Tsiklakis K, Tatakis DN. EDTA gel root conditioning: lack of effect on clinical and radiographic outcomes of intrabony defect treatment with enamel matrix derivative. $J$ Periodontol. 2006;77:103-110.

106. Sculean A, Berakdar M, Willershausen B, Arweiler NB, Becker J, Schwarz F. Effect of EDTA root conditioning on the healing of intrabony defects treated with an enamel matrix derivative. $J$ Periodontol. 2006;77:1167-1172.

107. Sculean A, Donos N, Blaes A, Lauermann M, Reich E, Brecx M. Comparison of enamel matrix proteins and bioabsorbable membranes in the treatment of intrabony periodontal defects: a split-mouth study. J Periodontol. 2004;70:255-262.

108. Sanz M, Tonetti MS, Zabalegui I, et al. Treatment of intrabony defects with enamel matrix proteins or barrier membranes: results from a multicenter practice-based clinical trial. $J$ Periodontol. 2004; 75:726-733.

109. Francetti L, Trombelli L, Lombardo G, et al. Enamel matrix proteins in the treatment of intrabony defects: a 24-month multicenter study. Int J Periodontics Restorative Dent. 2005;25:461-473.

110. Sculean A, Donos N, Miliauskaite A, Arweiler N, Brecx M. Treatment of intrabony defects with enamel matrix proteins or bioresorbable membranes: a 4-year follow up split-mouth study. $J$ Periodontol. 2001;72:1695-1701.

111. Cortellini P, Tonetti MS. A minimally invasive surgical technique with an enamel matrix derivative in the regenerative treatment of intrabony defects: a novel approach to limit morbidity. J Clin Periodontol. 2007;34:87-93. 
112. Ribeiro FV, Nociti Júnior FH, Sallum EA, Sallum AW, Casati MZ. Use of enamel matrix protein derivative with minimally invasive surgical approach in intra-bony periodontal defects: clinical and patientcentered outcomes. Braz Dent J. 2010;21:60-67.

113. Grusovin MG, Esposito M. The efficacy of enamel matrix derivative (Emdogain) for the treatment of deep infrabony periodontal defects: a placebo-controlled randomized clinical trial. Eur J Oral Implantol. 2009;2:43-54.

114. Sculean A, Donos N, Schwarz F, Becker J, Brecx M, Arweiler NB. Five-year results following treatment of intrabony defects with enamel matrix proteins and guided tissue regeneration. J Clin Periodontol. 2004;31:545-549.

115. Wikesjö UM, Selvig KA. Periodontal wound healing and regeneration. J Periodontol 2000. 1999;19:21-39.

116. Tonetti MS, Prato GP, Cortellini P. Factors affecting the healing response of intrabony defects following guided tissue regeneration and access flap surgery. J Clin Periodontol. 1996;23:548-556.

117. Sipos PM, Loos BG, Abbas F, Timmerman MF, van der Velden U. The combined use of enamel matrix proteins and a tetracycline-coated expanded polytetrafluoroethylene barrier membrane in the treatment of intra-osseous defects. J Clin Periodontol. 2005;32:765-772.

118. Sculean A, Windisch P, Keglevich T, Chiantella GC, Gera I, Donos N. Clinical and histological evaluation of human intrabony defects treated with an enamel matrix protein derivative combined with a bovine-derived xenograft. Int J Periodontics Restorative Dent. 2003;23:47-55

119. Sculean A, Windisch P, Keglevich T, Gera I. Clinical and histological evaluation of an enamel matrix protein derivative combined with a bioactive glass for the treatment of intrabony periodontal defects in humans. Int J Periodontics Restorative Dent. 2005;25:139-147.

120. Lekovic V, Camargo PM, Weinlaender M, Nedic M, Aleksic Z, Kenney EB. A comparison between enamel matrix proteins used alone or in combination with bovine porous bone mineral in the treatment of intrabony periodontal defects in humans. J Periodontol. 2000;71:1110-1116.

121. Velasquez-Plata D, Scheyer ET, Mellonig JT. Clinical comparison of an enamel matrix derivative used alone or in combination with a bovine-derived xenograft for the treatment of periodontal osseous defects in humans. J Periodontol. 2002;73:433-440.

122. Sculean A, Chiantella GC, Arweiler NB, Becker J, Schwarz F, Stavropoulos A. Five-year clinical and histologic results following treatment of human intrabony defects with a natural bone mineral. Int J Periodontics Restorative Dent. 2008;28:153-161.

123. Sculean A, Kiss A, Miliauskaite A, Schwarz F, Arweiler NB, Hannig M. Ten-year results following treatment of intra-bony defects with enamel matrix proteins and guided tissue regeneration. $J$ Clin Periodontol. 2008;35:817-824.

124. Zucchelli G, Amore C, Montebugnoli L, De Sanctis M. Enamel matrix proteins and bovine porous mineral in the treatment of intrabony defects: a comparative controlled clinical trial. $J$ Periodontol. 2003;74:1725-1735.

125. Gurinsky BS, Mills MP, Mellonig JT. Clinical evaluation of demineralized freeze dried bone allograft and enamel matrix derivative versus enamel matrix derivative alone for the treatment of periodontal osseous defects in humans. $J$ Periodontol. 2004;75:1309-1318.

126. Sculean A, Pietruska M, Schwarz F, Willershausen B, Arweiler NB, Auschill TM. Healing of human intrabony defects following regenerative periodontal therapy with an enamel matrix protein derivative alone or combined with a bioactive glass. J Clin Periodontol. 2005;32:111-117.

127. Listl S, Tu YK, Faggion CM Jr. A cost-effectiveness evaluation of enamel matrix derivative alone or in conjunction with regenerative devices alone or in conjunction with regenerative devices in the treatment of periodontal intra-osseous defects. J Clin Periodontol. 2010;37:920-927.
128. Yilmaz S, Cakar G, Yildirim B, Sculean A. Healing of two and three wall intrabony periodontal defects following treatment with an enamel matrix derivative combined with autogenous bone. J Clin Periodontol. 2010;37:544-550.

129. Baltacioglu E, Tasdemir T, Yuva P, Celik D, Sukuroglu E. Intentional replantation of periodontally hopeless teeth using a combination of EMD and demineralized freeze-dried bone allograft. Int $J$ Periodontics Restorative Dent. 2011;31:75-81.

130. Sculean A, Barbé G, Chiantella GC, Arweiler NB, Berakdar M, Brecx M. Clinical evaluation of an enamel matrix protein derivative combined with a bioactive glass for the treatment of intrabony periodontal defects in humans. J Periodontol. 2002;73:401-408.

131. Sculean A, Chiantella GC, Windisch P, Gera I, Reich E. Clinical evaluation of an enamel matrix protein derivative $\left(\right.$ Emdogain $\left.^{\circledR}\right)$ combined with a bovine derived xenograft $\left(\mathrm{Bio}^{-O s s^{\circledR}}\right.$ ) for the treatment of intrabony periodontal defects in humans. Int J Periodontics Restorative Dent. 2002;22:259-267.

132. Modica F, Del Pizzo M, Roccuzzo M, Romagnoli R. Coronally advanced flap for the treatment of buccal gingival recessions with and without enamel matrix derivative: a split-mouth study. J Periodontol. 2000;71:1693-1698.

133. Hagewald S, Spahr A, Rompola E, Haller B, Heijl L, Bernimoulin JP. Comparative study of Emdogain ${ }^{\circledR}$ and coronally advanced flap technique in the treatment of human gingival recessions: a prospective controlled clinical study. J Clin Periodontol. 2002;29:35-41.

134. Spahr A, Hagewald S, Tsoulfidou F, et al. Coverage of Miller class I and II recession defects using enamel matrix proteins versus coronally repositioned flap technique: a 2-year report. $J$ Periodontol. 2005;76:1871-1880.

135. Cueva MA, Boltchi FE, Hallmon WW, Nunn ME, Rivera-Hidalgo F, Rees T. A comparative study of coronally advanced flaps with and without the addition of enamel matrix derivative in the treatment of marginal tissue recession. J Periodontol. 2004;75:949-956.

136. Castellanos A, de la Rosa M, de la Garza M, Caffesse RG. Enamel matrix derivative and coronal flaps to cover marginal tissue recessions. J Periodontol. 2006;77:7-14.

137. McGuire MK, Nunn M. Evaluation of human recession defects treated with coronally advanced flaps and either enamel matrix derivative or connective tissue. 1. Comparison of clinical parameters. J Periodontol. 2003;74:1110-1125.

138. Nemcovsky CE, Artzi Z, Tal H, Kozlovsky A, Moses O. A multicenter comparative study of two root coverage procedures: coronally advanced flap with addition of enamel matrix proteins and subpedicle connective tissue graft. J Periodontol. 2004;75:600-607.

139. Berlucchi I, Francetti L, Del Fabbro M, Testori T, Weinstein RL. Enamel matrix proteins (Emdogain) in combination with coronally advanced flap or subepithelial connective tissue graft in the treatment of shallow gingival recessions. Int $J$ Periodontics Restorative Dent. 2002;22:583-593.

140. Kuru BH. Treatment of localized gingival recessions using enamel matrix derivative as an adjunct to laterally sliding flap: 2 case reports. Quintessence Int. 2009;40:461-469.

141. Aroca S, Keglevich T, Nikolidakis D, et al. Treatment of class III multiple gingival recessions: a randomized clinical trial. J Clin Periodontol. 2010;37:88-97.

142. Rasperini G, Roccuzzo M, Francetti L, Acunzo R, Consonni D, Silvestri M. Subepithelial connective tissue graft for treatment of gingival recessions with and without enamel matrix derivative: a multicenter, randomized controlled clinical trial. Int J Periodontics Restorative Dent. 2011;31:133-139.

143. Jepsen S, Heinz B, Jepsen K, et al. A randomized clinical trial comparing enamel matrix derivative and membrane treatment of buccal class II furcation involvement in mandibular molars. I. Study design and results for primary outcome. $J$ Periodontol. 2004;75: $1150-1160$. 
144. Meyle J, Gonzales JR, Bödeker RH, et al. A randomized clinical trial comparing enamel matrix derivative and membrane treatment in mandibular molars. II. Secondary outcomes. J Periodontol. 2004;75: 1188-1195.

145. Casarin RC, Ribeiro Edel P, Nociti FH Jr, et al. Enamel matrix derivative proteins for the treatment of proximal class II furcation involvements: a prospective 24-month randomized clinical trial. J Clin Periodontol. 2010;37:1100-1109.

146. Lafzi A, Farahani RM, Tubbs RS, Roushangar L, Shoja MM. Enamel matrix derivative Emdogain ${ }^{\circledR}$ as an adjuvant for a laterally-positioned flap in the treatment of gingival recession: an electron microscopic appraisal. Folia Morphol (Warsz). 2007;66:100-102.
147. Sabbarini J, Mounir M, Dean J. Histological evaluation of enamel matrix derivative as a pulpotomy agent in primary teeth. Pediatr Dent. 2007;29:475-479.

148. Lyngstadaas SP, Wohlfahrt JC, Brookes SJ, Paine ML, Snead ML, Reseland JE. Enamel matrix proteins; old molecules for new applications. Orthod Craniofac Res. 2009;12:243-253.

\section{Publish your work in this journal}

Clinical, Cosmetic and Investigational Dentistry is an international, peer-reviewed, open access, online journal focusing on the latest clinical and experimental research in dentistry with specific emphasis on cosmetic interventions. Innovative developments in dental materials, techniques and devices that improve outcomes and patient satisfac- tion and preference will be highlighted. The manuscript management system is completely online and includes a very quick and fair peerreview system, which is all easy to use. Visit http://www.dovepress. com/testimonials.php to read real quotes from published authors.

Submit your manuscript here: http://www.dovepress.com/clinical-cosmetic-and-investigational-dentistry-journal 